Article

\title{
Sustainable Extraction of Chitin from Spent Pupal Shell of Black Soldier Fly
}

\author{
Yin-Shen Lin ${ }^{1}$, Shih-Hsiang Liang ${ }^{2}$, Wen-Lin Lai ${ }^{3,4}{ }^{\text {, Ja-Xin Lee }}{ }^{2}$, Ya-Peng Wang ${ }^{1}$, Yi-Tsz Liu ${ }^{1}$, Szu-Han Wang ${ }^{2}$ \\ and Meng-Hwan Lee ${ }^{1, *(1)}$
}

1 Division of Animal Technology, Animal Technology Research Center, Agricultural Technology Research Institute, No. 52 Kedong 2 Rd., Zhunan Township, Miaoli County 35053, Taiwan; chris112783@mail.atri.org.tw (Y.-S.L.); 1062042@mail.atri.org.tw (Y.-P.W.); 1052039@mail.atri.org.tw (Y.-T.L.)

2 Hsinchu Branch, Livestock Research Institute, Council of Agriculture, Miaoli County 36841, Taiwan; shliang@tlri.gov.tw (S.-H.L.); jxlee@tlri.gov.tw (J.-X.L.); shwang@tlri.gov.tw (S.-H.W.)

3 Department of Medical Laboratory and Biotechnology, Chung Shan Medical University, Taichung 40201, Taiwan; wllai@csmu.edu.tw

4 Clinical Laboratory, Chung Shan Medical University Hospital, Taichung 40201, Taiwan

* Correspondence: mhlee@mail.atri.org.tw; Tel.: +886-37-585799

check for updates

Citation: Lin, Y.-S.; Liang, S.-H.; Lai, W.-L.; Lee, J.-X.; Wang, Y.-P.; Liu, Y.-T.; Wang, S.-H.; Lee, M.-H. Sustainable Extraction of Chitin from Spent Pupal Shell of Black Soldier Fly. Processes 2021, 9, 976. https://doi.org/ $10.3390 /$ pr9060976

Academic Editor: Shao-Wen Hung

Received: 12 May 2021

Accepted: 29 May 2021

Published: 31 May 2021

Publisher's Note: MDPI stays neutral with regard to jurisdictional claims in published maps and institutional affiliations.

Copyright: (c) 2021 by the authors. Licensee MDPI, Basel, Switzerland. This article is an open access article distributed under the terms and conditions of the Creative Commons Attribution (CC BY) license (https:// creativecommons.org/licenses/by/ $4.0 /)$.

\begin{abstract}
Chitin and its deacetylated derivative chitosan are used for application in areas as an agriculture, biomedicine, cosmetic, food, textile and chelating agent for wastewater treatment. The current extraction of chitin is based on a chemical process using hydrochloric acid and sodium hydroxide. The main disadvantage of the process is the generation of large volumes of acid and alkaline effluents, which require further treatment before release. Chitin was extracted from spent pupal shell of black soldier fly (BSF) by the microbial fermentation method using Bacillus lichenformis A6. The recovery rate of chitin content by the microbial fermentation method was found to be about $12.4 \%$. The structures of BSF chitin and chitosan were further characterized by FTIR, XRD, and SEM. Our results showed that the chitin obtained from BSF was observed in $\alpha$ form. The crystalline index values of chitin and chitosan are $52.8 \%$ and $55.4 \%$, respectively. The surface morphology was examined by SEM, revealing nanofiber structures. The spent pupal shell of BSF may be used as alternative chitin sources for various technological purposes.
\end{abstract}

Keywords: Chitin; Chitosan; Black Soldier Fly; Hermetia illucens; Bacillus lichenformis A6

\section{Introduction}

Chitin, a linear polymer of $\beta(1-4)$ linked $N$-acetyl-D-glucosamine and D-glucosamine, is the second most abundant natural carbohydrate polymer after cellulose. Chitin is also the most abundant nitrogen-containing biopolymers (aminopolysaccharide polymer). Chitin is usually distributed in marine invertebrates, insects, fungi and yeast. Chitin of fungi and yeast is mixed with proteins and polysaccharides rendering the separation. The shells of crustaceans and insects consist of calcium carbonate (20-50\%), protein (20-40\%) and chitin (15-40\%). The majority of commercial chitin products were purified from the shells of harvested crustaceans because this prevents waste products and is the most readily available material for large-scale marine food processing industry [1,2].

Chitin and its deacetylated derivative chitosan are used for application in areas as agriculture, biomedicine, cosmetics, food, textile and chelating agent for wastewater treatment [3]. Three types of reactive functional groups are present in chitosan including an amino group at the C-2 position, and both primary and secondary hydroxyl groups at the C-3 and C-6 positions, respectively. The structures and bioactivities of chitosan are greatly influenced by their amino contents [4,5].

Currently, the commercially available source of chitin is the exoskeletons of shrimps and crabs. In the commercial chitin, it was extracted by acidic removal of calcium carbonate 
followed by alkaline extraction of proteins and alkaline peroxide bleaching. However, the relatively high calcium, wax, and pigment contents of crustacean exoskeletons cause the extraction of chitosan to be time-consuming and labor-intensive [6].

Several works reported the isolation of chitin and chitosan from the cuticle of insects, but these sources are not suitable for industrial manufacturing. Certain species of insects (e.g., honeybees, silkworms, and house flies) can be reared artificially accumulation of chitin-containing material and can be used for industrial processing [7]. Nowadays, the mass-rearing technology and scalability of black soldier fly (BSF, Hermetia illucens) are becoming increasingly popular worldwide. Due to the ability to quickly convert organic wastes into larval biomass, BSF have become one of the main species for mass-rearing which can be used as food and feed [8,9].

Two global problems - feed protein deficiency and organic waste utilization-have been proposed to be solved simultaneously by BSF treatment as a new strategy in the concept of a circular economy. Almost one-third of all food produced (almost 1.6 billion tons per year) for human consumption in the world is wasted according to the report from Food and Agriculture Organization (FAO) of the United Nations. Several methods (e.g., incineration, composting and landfilling) are used to manage organic wastes. However, BSF treatment is considered to be more sustainable and economically viable. For instance, research results show that direct $\mathrm{CO}_{2} \mathrm{eq}$ emissions from BSF treatment are 47 times lower the emissions from composting [10]. With rearing BSF, the pupal shell containing chitin-rich material is left as a by-product. Therefore, it would be possible to both increase the effectiveness of the BSF rearing method and obtain valuable biopolymers with development of the BSF-based technology. In this work, a microbial fermentation method was developed for the isolation and determination of chitin in BSF pupal shell. The method is found to be more suitable, compared to traditional methods, for large-scale manufacturing.

\section{Materials and Methods}

\subsection{Material}

BSF were reared on soybean curd residues in the farm in Miaoli County of Taiwan. The BSF spent pupal shells were collected and washed in running tap water to remove impurities. The washed shells were then dried in an oven at $65^{\circ} \mathrm{C}$ and ground in a knife mill to produce fragments of 0.1 to $0.2 \mathrm{~cm}$. Commercial chitosan from shrimp shells with a deacetylation degree of $75 \%$ was used as a standard. All used reagents of analytical purity were purchased from Sigma-Aldrich (St. Louis, MO, USA).

\subsection{Microorganism and Cultivation}

Bacillus lichenformis A6 used for removing protein from BSF pupal shell was isolated from an alkaliphilic culture and propagated in yeast peptone dextrose (YPD) medium ( $1 \%$ yeast extract, $2 \%$ peptone, $2 \%$ dextrose).

\subsection{Chitin Extraction by Biological Method}

Bacillus lichenformis A6 was activated on YPD fluid medium at $37^{\circ} \mathrm{C}, 180 \mathrm{rpm}$ for 2 days. Then, $30 \mathrm{~mL}$ of the preculture was transferred into $300 \mathrm{~mL}$ of $1 \%$ glucose ( $\mathrm{pH} 10)$ with $30 \mathrm{~g}$ of grounded BSF shell. The culture was performed on a rotatory shaker at $37^{\circ} \mathrm{C}$, $180 \mathrm{rpm}$ for 10 days. The fermented BSF shell powder was washed, sieved and dried.

\subsection{Decoloration}

The chitin residue was mixed with $0.1 \%$ SDS, $0.5 \%$ sodium bicarbonate at a solid/solvent ratio of $1: 10(w / v)$ heated to $75{ }^{\circ} \mathrm{C}$, followed by bleaching with $30 \% \mathrm{H}_{2} \mathrm{O}_{2}$ for $48 \mathrm{~h}$. Then residue was washed with water and filtered, and oven-dried at $65{ }^{\circ} \mathrm{C}$ for one day to obtain chitin. 


\subsection{Deacetylation}

Strong alkaline solution was used for the deacetylation conversion of chitin to chitosan. About $1 \mathrm{~g}$ of chitin was mixed in $50 \mathrm{~mL}$ of $50 \%$ sodium hydroxide solution at $95{ }^{\circ} \mathrm{C}$ under constant stirring. After $4 \mathrm{~h}$ stirring, the solid was filtered and washed with distilled water until the filtrate was neutral. Then the solid was oven-dried at $80^{\circ} \mathrm{C}$ overnight.

\subsection{Determination of the Degree of Deacetylation (DDA)}

The degree of deacetylation of chitosan was measured by the UV method [11]. Dried chitosan sample $(0.1 \mathrm{~g})$ was dissolved in $19.5 \mathrm{~mL} 5 \%$ acetic acid and $30 \mathrm{~mL}$ deionized water. After 10 min stirring, the chitosan sample solution can be determined by measuring the solution absorbance at $199 \mathrm{~nm}$ determined on a UV-vis Spectrophotometer. According to the standard curve prepared using $\mathrm{N}$-acetylglucosamine range from 0.01 to $0.05 \mathrm{mg} / \mathrm{mL}$ dissolved in $2 \%$ acetic acid solution, the concentration of acetyl can be determined DDA can be calculated according to the equation

$$
\mathrm{DDA}=100 \%-\mathrm{C} 1 / \mathrm{C}
$$

where $\mathrm{C} 1$ is the acetyl concentration of chitosan sample and $\mathrm{C}$ is concentration of chitosan sample.

\subsection{X-ray Diffraction (XRD) Analysis}

The XRD experiment was performed at $30 \mathrm{kV}, 10 \mathrm{~mA}$, and $2 \theta$ with a $\mathrm{CuK} \alpha 1$ radiation source and a scan angle from 5 to $30^{\circ}$ using a Shimadzu Labx XRD 6000 system (Tokyo, Japan). The crystalline indices (CrI) of chitin were calculated as

$$
\mathrm{CrI}_{110}=\left[\left(\mathrm{I}_{110}-\mathrm{I}_{\mathrm{am}}\right) / \mathrm{I}_{110}\right] \times 100
$$

where $\mathrm{I}_{110}=$ maximum intensity at $2 \theta \cong 20^{\circ}$ and $\mathrm{I}_{\mathrm{am}}=$ intensity of amorphous diffraction at $2 \theta \cong 16^{\circ}$.

\subsection{Fourier Transformation Infrared Spectroscopy (FTIR)}

The FTIR spectra were measured on $\mathrm{KBr}$ pellet method in transmission mode in the range of $400 \mathrm{~cm}^{-1}$ to $4000 \mathrm{~cm}^{-1}$ using FTIR (Varican-1000, PIKE Technologies, Madison, WI, USA).

\subsection{Scanning Electron Microscopy (SEM)}

The surface structures of the BSF chitin and chitosan were investigated by a Scanning Electron Microscope (JSM-5600 JEOL, Tokyo, Japan) operated at $20 \mathrm{kV}$. Gatan Precision Etching Coating System (PECS, Gatan Inc., Pleasanton, CA, USA) was used to gold cover the samples.

\subsection{Metal Content Analysis}

The concentrations of metals $(\mathrm{As}, \mathrm{Pb}, \mathrm{Cd}$, and $\mathrm{Hg}$ ) of chitosan samples were determined for the using inductively coupled plasma mass spectrometry (ICP/MS, Thermo Fisher Scientific, Bremen, Germany).

\subsection{Antimicrobial Activity Assay}

The minimum inhibitory concentration (MIC) of BSF chitosan was determined using the microdilution broth method in 96-well microtiter plates. BSF chitosan was solubilized in $1 \%$ acetic acid at a final concentration of $10 \mathrm{mg} / \mathrm{mL}$. A volume of $100 \mu \mathrm{L}$ chitosan solution was added over trypticase soy broth (TSB) in the first well and two-fold serial dilution was performed to obtain a range of concentrations between $0.156-10 \mathrm{mg} / \mathrm{mL}$. Microbial suspensions were prepared from Staphylococcus aureus (ATCC 25923) and Pseudomonas aeruginosa (ATCC 27853) grown on TSB at $37^{\circ} \mathrm{C}$ for $24 \mathrm{~h}$. The bacterial inoculum was added to give a final concentration of $1.5 \times 10^{8} \mathrm{cfu} / \mathrm{mL}$ in each well and incubated at $37^{\circ} \mathrm{C}$. The MIC 
value was defined as the lowest concentration of samples that inhibited the tested microorganisms' growth, compared to the untreated culture (growth control). The experiment was performed in triplicate. After the MIC determination, aliquots of $50 \mu \mathrm{L}$ from all wells which showed no visible bacterial growth were seeded in TSA (trypticase soy agar) plates incubated for $24 \mathrm{~h}$ at $37^{\circ} \mathrm{C}$. The $\mathrm{MBC}$ is defined as the lowest concentration of samples that kills more than $99.9 \%$ of the initial bacterial population.

\section{Results}

\subsection{Extract Chitin by Fermentation}

BSF spent pupal shell can be used a potential chitin-rich source for the extraction of chitin and chitosan. The BSF larva has some unique features. Firstly, it contains a high amount of lipids and also very few fermentable sugars. Secondly, melanin covalently bound to chitin. Glucose is used as the carbohydrate source for this fermentation extraction of chitin from spent pupal shell of BSF. After 10 days fermentation, The BSF shell powder was washed, sieved and dried. Chitosan production process follows the standard procedure of deacetylation steps. The recovery rate of chitin content by microbial fermentation method was found to be about $12.4 \%$. As shown in Table 1, the degree of deacetylation (DDA) of chitosan was about $81.5 \%$.

Table 1. Extraction of chitin from BSF spent pupal shell.

\begin{tabular}{cccccc}
\hline & Protein $\mathbf{( \% )}$ & $\begin{array}{c}\text { Ash } \\
\mathbf{( \% )}\end{array}$ & $\begin{array}{c}\text { DP } \\
\mathbf{( \% )}\end{array}$ & $\begin{array}{c}\text { DM } \\
\mathbf{( \% )}\end{array}$ & $\begin{array}{c}\text { DDA } \\
\mathbf{( \% ) ~ d t )}\end{array}$ \\
\hline $\begin{array}{c}\text { Pupal shell } \\
\text { Biological fermentation }\end{array}$ & 62.10 & 8.21 & - & - & - \\
\hline
\end{tabular}

All results shown are the mean of three determinations. DP: the efficacy of deproteinization. DM: the efficacy of demineralization. DDA: the degree of deacetylation.

\subsection{FTIR Analysis}

The Fourier Transformed Infrared-Red (FTIR) spectra of chitin and chitosan obtained BSF pupal shell are shown in Figure 1. The spectrum of chitin shows the usual characteristic bands at $3450 \mathrm{~cm}^{-1}(\mathrm{O}-\mathrm{H}), 2880 \mathrm{~cm}^{-1}(\mathrm{C}-\mathrm{H}), 1655 \mathrm{~cm}^{-1}$ (amide I), $1550 \mathrm{~cm}^{-1}$ (amide II) and $1310 \mathrm{~cm}^{-1}$ (amide III). Compared with the spectrum of chitin, the peak at $1550 \mathrm{~cm}^{-1}$ disappeared in the spectrum of chitosan after deacetylation (Figure 1B).
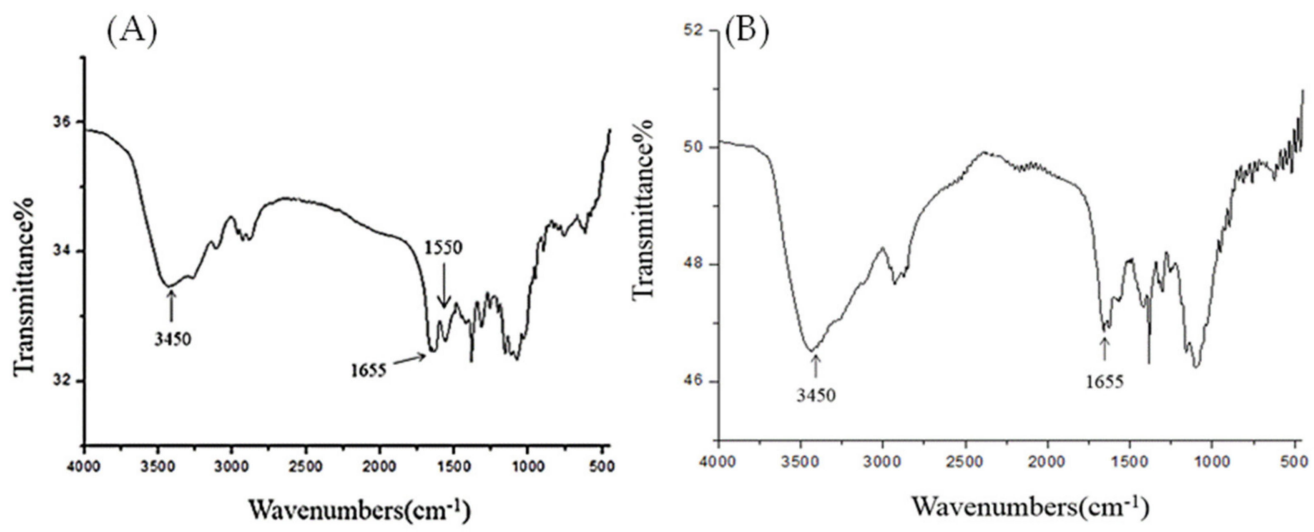

Figure 1. Fourier Transformed Infrared-Red (FTIR) of chitin and chitosan extracted from BSF pupal shell. (A) Chitin; (B) Chitosan.

\subsection{XRD Analysis}

The crystal structures of BSF chitin and chitosan characterized by XRD analysis are shown in Figure 2. The diffraction pattern of chitin and chitosan shows strong reflections at $2 \theta$ around 9.3 and 19.3. The peaks of the diffraction pattern are high and sharp, indicating a highly ordered crystal structure of $\alpha$-chitin. The crystalline indexes (CrI) of chitins 
extracted from different organisms vary depending on the hardness of their sources. In our study, the CrI value of chitin extracted from BSF pupal shell (52.8\%) and chitosan (55.4\%) corresponded to lower crystalline index values. In a study by Zhang et al. [12], the crystalline value was determined to be $54 \%$ and $58 \%$ in beetle larva cuticles and silkworm pupa exuvia, similar to the values in our study. The crystalline index value of chitosan has been reported to be very important and chitosan with a lower crystalline structure to be superior for use in waste water treatment to remove pollutants such as heavy metal ions and dyes [13].

(A)

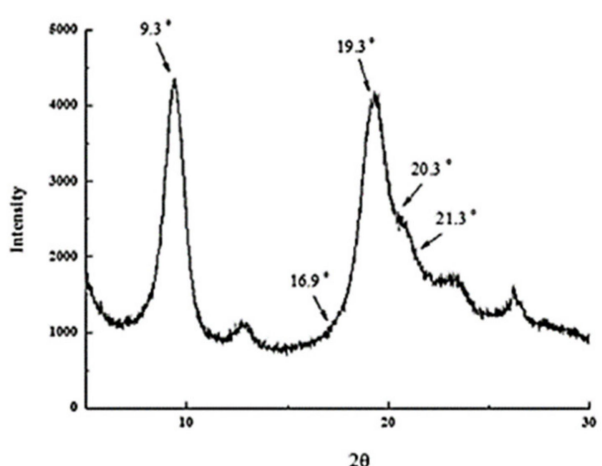

(B)

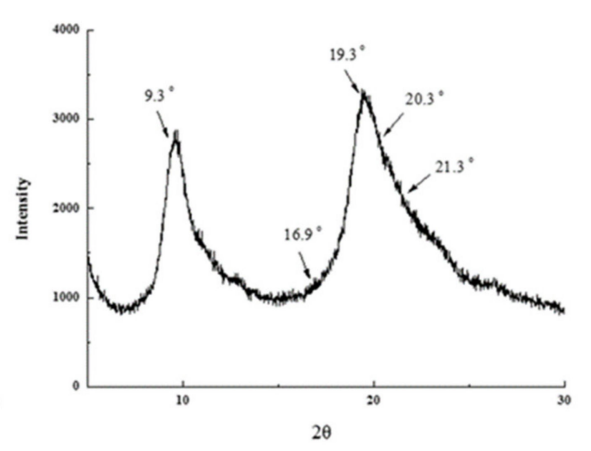

Figure 2. XRD analysis of chitin and chitosan extracted from BSF pupal shell. (A) Chitin; (B) Chitosan.

\subsection{SEM}

SEM images of BSF chitin and chitosan are shown in Figure 3. Both the BSF chitin and chitosan samples had a smooth surface morphology with nonporous structure and well-organized repeating units of hexagonal microfibrillar form resembling a honeycomb.
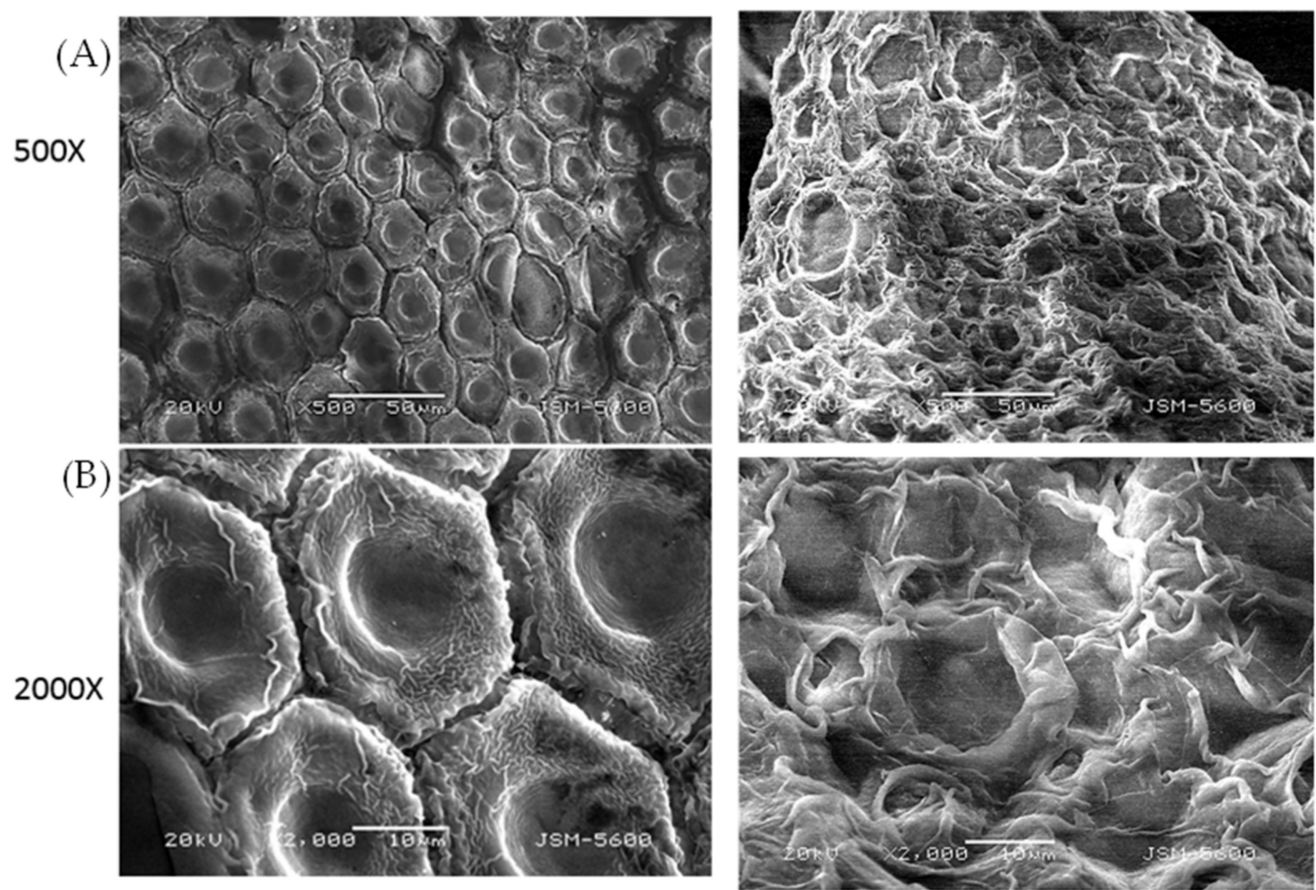

(C)

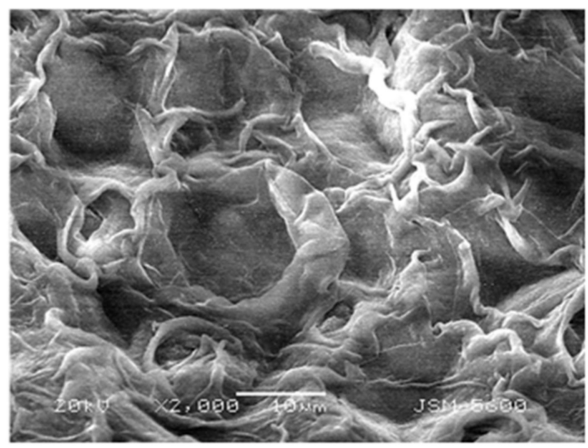

(D)

Figure 3. Scanning electron microscope of chitin and chitosan extracted from BSF pupal shell. (A) Chitin 500 $\times$; (B) Chitin 2000×; (C) Chitosan 500×; (D) Chitosan 2000×. 


\subsection{Metal Content}

In this study, chitosan were extracted from BSF which feed with soybean residues. Metals content were determined and results shown in Table 2. Four metals content (arsenic, lead, cadmium, mercury) should be followed the feed management guideline in Taiwan. The values of metals content in BSF chitosan were $0.08(\mathrm{As}), 2.89(\mathrm{~Pb}), 0.40(\mathrm{Cd}) \mathrm{ppm}$ and mercury content was below the limit of quantification. Four metals content in BSF chitin samples were all below the guide requirements.

Table 2. The metal content of BSF chitosan.

\begin{tabular}{cccc}
\hline & BSF Chitosan (PPM) & $\begin{array}{c}\text { Guide Requirement } \\
\text { (PPM) }\end{array}$ & $\begin{array}{c}\text { Limit of Quantification } \\
\text { (PPM) }\end{array}$ \\
\hline arsenic $(\mathrm{As})$ & 0.08 & 12 & 0.01 \\
lead $(\mathrm{Pb})$ & 2.89 & 50 & 0.01 \\
cadmium $(\mathrm{Cd})$ & 0.40 & 10 & 0.01 \\
mercury $(\mathrm{Hg})$ & N.D. & 0.5 & 0.01 \\
\hline
\end{tabular}

\subsection{Antimicrobial Effect of BSF Chitosan}

The MIC and MBC of BSF chitosan upon Pseudomonas aeruginosa and Staphylococcus aureus were determined and results are reported in Table 3. The results showed the BSF chitosan exerts strong bactericidal effects against $P$. aeruginosa. The MBC and MIC values for $S$. aureus were $1.25 \mathrm{mg} / \mathrm{mL}$ and $0.60 \mathrm{mg} / \mathrm{mL}$ respectively higher than against for P. aeruginosa.

Table 3. The inhibition parameters of chitosan.

\begin{tabular}{cccc}
\hline Test Component & Bacterial Strain & $\begin{array}{c}\text { MBC } \\
(\mathbf{m g} / \mathbf{m L})\end{array}$ & $\begin{array}{c}\mathbf{M I C} \\
\mathbf{( m g / m L}\end{array}$ \\
\hline BSF Chitosan & $\begin{array}{c}\text { Staphylococcus aureus (ATCC 25923) } \\
\text { Pseudomonas aeruginosa } \\
\text { BSF Chitosan }\end{array}$ & 1.25 & 0.60 \\
$\begin{array}{c}\text { Sigma-MMW Chitosan } \\
(190 \mathrm{kDa} \sim 310 \mathrm{kDa})\end{array}$ & $\begin{array}{c}\text { Pseudomonas aeruginosa } \\
\text { (ATCC 27853) }\end{array}$ & 0.16 & 0.04 \\
$\begin{array}{c}\text { Sigma-LMW Chitosan } \\
(50 \mathrm{kDa} 190 \mathrm{kDa})\end{array}$ & $\begin{array}{c}\text { Pseudomonas aeruginosa } \\
\text { (ATCC 27853) }\end{array}$ & 0.35 & 0.13 \\
\hline
\end{tabular}

MMW: medium molecular weight. LMW: low molecular weight.

In this study, the MBC and MIC were also determined for P. aeruginosa with different molecular weight of commercial chitosan and compared to BSF chitosan. In Table 3, our data showed stronger bactericidal and bacteriostatic effect on LMW (low-molecular-weight) chitosan than MMW (medium molecular weight) chitosan. BSF chitosan showed stronger bactericidal effects for P. aeruginosa than two kinds of commercial chitosan.

\section{Discussion}

The content of chitin varies significantly in different BSF lifecycle stages and is mostly diet-independent. The physicochemical structure of chitin isolated from BSF was first reported in 2016 [14]. The chitin was extracted both from larvae and imago by conventional chemical method. The study showed that the BSF chitin were present in $\alpha$ crystalline form [14]. In a recent study [15], the chitin were extracted both from BSF pupal exuviae and imago, and the chitin content of pupal exuviae was $23 \%$ of BSF dry body weight. Similar to our study, the authors found that the physical characteristics of BSF chitin were $\alpha$-chitin, and the structure of exuviae chitin was amorphous and nonporous.

The current extraction of chitin is based on chemical-catalyzed process, using hydrochloric acid and sodium hydroxide. The main disadvantage of this technology is that it raises environmental concerns to generate large volumes of acidic and alkaline effuents, which require further treatment before release. The main purpose of this study is to replace 
the chemicals and thereby achieve sustainable, green production of chitin. In this study, we used Bacillus licheniformis A6 strain in the BSF fermentation. In general, B. licheniformis can therefore be considered nonpathogenic to humans. B. licheniformis can be used in animal feed and used as probiotics for human consumption [16,17]. B. licheniformis can also be used as biofertilization to improve the functional quality of tomato including the lycopene content, flavonoids content and antioxidant activity under greenhouse conditions [18].

In the study of biologically extraction of chitin from shrimp head waste, two bacterial strains were synergistic combined with a protease-producing bacterium, B. licheniformis 21,886 , and an acid-producing bacterium, Gluconobacter oxydans DSM-2003. When the shrimp head waste was cofermented with B. licheniformis followed by G. oxydans, the deproteinization (DP) and demineralization (DM) efficiencies were 87 and 93.5\% respectively [19]. In the cofermenation with B. licheniformis, three times more organic acids, such as lactic, formic and acetic acid, were released than in the monofermentation of G. oxydans. In our study, monofermented with B. licheniformis A6 with BSF spent pupal shell, the deproteinization (DP) and demineralization (DM) efficiencies were 87.9 and $97.2 \%$ respectively.

Previous studies reported the antimicrobial activity of chitosan is strongly influenced by its molecular weight [20]. For P. aeruginosa, a Gram-negative bacteria, the antimicrobial activity of chitosan was enhanced as the molecular weight decreased. In contrast, for S. aureus, a Gram-positive bacteria, the antimicrobial activity of chitosan increased with increasing molecular weight. This may be a result of the differences in bacterial metabolism between Gram-positive bacteria and Gram-negative bacteria. One of the confirmed mechanisms is that the chitosan tends to form a coating over the bacteria at higher concentrations, not necessarily attached to the surface and independent of the bacteria type. Another mechanism was the interaction between positively charged chitosan molecules and negatively charged microbial cell membranes, thus provoking internal osmotic imbalances and consequently inhibiting the growth of micro-organisms [21,22]. The antibacterial activity of chitosan concentration of was higher in $S$. aureus than $P$. aeruginosa matched up to those two mechanisms in our study.

Author Contributions: S.-H.L., J.-X.L., S.-H.W., and M.-H.L. conceived and planned the experiments. S.-H.L., Y.-P.W., Y.-T.L., and W.-L.L. carried out the experiments. Y.-S.L. and M.-H.L. took the lead in writing the manuscript. All authors provided critical feedback and helped shape the research, analysis, and manuscript. All authors have read and agreed to the published version of the manuscript.

Funding: This research was funded by grant 110AS-10.1.4-ST-L4 from the Council of Agriculture, Taiwan.

Institutional Review Board Statement: Not applicable.

Informed Consent Statement: Not applicable.

Data Availability Statement: Not applicable.

Acknowledgments: The authors would like to thank Chao-Ling Yao at Yuan Ze University for technical supports.

Conflicts of Interest: The authors declare no conflict of interest.

\section{References}

1. Kaur, S.; Dhillon, G.S. Recent trends in biological extraction of chitin from marine shell wastes: A review. Crit. Rev. Biotechnol. 2015, 35, 44-61. [CrossRef] [PubMed]

2. Arbia, W.; Arbia, L.; Adour, L.; Amrane, A. Chitin extraction from crustacean shells using biological methods-A review. Food Tech. Biotechnol. 2013, 51, 12-25.

3. Mincea, M.; Negrulescu, A.; Ostafe, V. Preparation, modification, and applications of chitin nanowhiskers: A review. Rev. Adv. Mater. Sci. 2012, 30, 225-242.

4. Ravi Kumar, M.N.V. A review of chitin and chitosan applications. React. Funct. Polym. 2000, 46, 1-27. [CrossRef]

5. Hamed, I.; Özogul, F.; Regenstein, J.M. Industrial applications of crustacean by-products (chitin, chitosan, and chitooligosaccharides): A review. Trends Food Sci. Technol. 2016, 48, 40-50. [CrossRef] 
6. Philibert, T.; Lee, B.H.; Fabien, N. Current status and new perspectives on chitin and chitosan as functional biopolymers. Appl. Biochem. Biotechnol. 2017, 181, 1314-1337. [CrossRef] [PubMed]

7. Mohan, K.; Ganesan, A.R.; Muralisankar, T.; Jayakumar, R.; Sathishkumar, P.; Uthayakumar, V.; Chandirasekar, C.; Revathi, N. Recent insights into the extraction, characterization, and bioactivities of chitin and chitosan from insects. Trends Food Sci. Technol. 2020, 105, 17-42. [CrossRef]

8. D'Hondt, E.; Soetemans, L.; Bastiaens, L.; Maesen, M.; Jespers, V.; Bosch, B.V.D.; Voorspoels, S.; Elst, K. Simplified determination of the content and average degree of acetylation of chitin in crude black soldier fly larvae samples. Carbohydr. Res. 2020, 488, 107899. [CrossRef]

9. Bulak, P.; Polakowski, C.; Nowak, K.; Wako, A.; Wicek, D.; Bieganowski, A. Hermetia illucens as a new and promising species for use in entomoremediation. Sci. Total Environ. 2018, 633, 912-919. [CrossRef]

10. Mertenat, A.; Diener, S.; Zurbrügg, C. Black Soldier Fly biowaste treatment-Assessment of global warming potential. Waste Manag. 2019, 84, 173-181. [CrossRef]

11. Yuan, Y.; Chesnutt, B.M.; Haggard, W.O.; Bumgardner, J.D. Deacetylation of chitosan: Material characterization and in vitro evaluation via albumin adsorption and pre-osteoblastic cell cultures. Materials 2011, 4, 1399-1416. [CrossRef]

12. Zhang, M.; Haga, A.; Sekiguchi, H.; Hirano, S. Structure of insect chitin isolated from beetle larva cuticle and silkworm (Bombyx mori) pupa exuvia. Int. J. Biol. Macromol. 2000, 27, 99-105. [CrossRef]

13. Kaya, M.; Baran, T.; Menteş, A.; Asaroglu, M.; Sezen, G.; Tozak, K.O. Extraction and characterization of $\alpha$-chitin and chitosan from six different aquatic invertebrates. Food Biophys. 2014, 9, 145-157. [CrossRef]

14. Waśko, A.; Bulak, P.; Polak-Berecka, M.; Nowak, K.; Polakowski, C.; Bieganowski, A. The first report of the physicochemical structure of chitin isolated from Hermetia illucens. Int. J. Biol. Macromol. 2016, 92, 316-320. [CrossRef]

15. Purkayastha, D.; Sarkar, S. Physicochemical structure analysis of chitin extracted from pupa exuviae and dead imago of wild black soldier fly (Hermetia illucens). J. Polym. Environ. 2020, 28, 445-457. [CrossRef]

16. Cutting, S.M. Bacillus probiotics. Food Microbiol. 2011, 28, 214-220. [CrossRef]

17. Nithya, V.; Halami, P.M. Evaluation of the probiotic characteristics of Bacillus species isolated from different food sources. Ann. Microbiol. 2013, 63, 129-137. [CrossRef]

18. Ochoa-Velasco, C.E.; Valadez-Blanco, R.; Salas-Coronado, R.; Sustaita-Rivera, F.; Hernández-Carlos, B.; García-Ortega, S.; Santos-Sánchez, N.F. Effect of nitrogen fertilization and Bacillus licheniformis biofertilizer addition on the antioxidants compounds and antioxidant activity of greenhouse cultivated tomato fruits (Solanum lycopersicum L. var. Sheva). Sci. Hortic. 2016, 201, 338-345. [CrossRef]

19. Liu, P.; Liu, S.; Guo, N.; Mao, X.; Lin, H.; Xue, C.; Wei, D. Cofermentation of Bacillus licheniformis and Gluconobacter oxydans for chitin extraction from shrimp waste. Biochem. Eng. J. 2014, 91, 10-15. [CrossRef]

20. Sahariah, P.; Másson, M. Antimicrobial Chitosan and Chitosan Derivatives: A Review of the Structure-Activity Relationship. Biomacromolecules 2017, 18, 3846-3868. [CrossRef]

21. Zheng, L.Y.; Zhu, J.F. Study on antimicrobial activity of chitosan with different molecular weights. Carbohydr. Polym. 2003, 54, 527-530. [CrossRef]

22. Costa, E.M.; Silva, S.; Pina, C.; Tavaria, F.K.; Pintado, M.M. Evaluation and insights into chitosan antimicrobial activity against anaerobic oral pathogens. Anaerobe 2012, 18, 305-309. [CrossRef] [PubMed] 